\title{
ANALISIS POTENSI KERUSAKAN TANAH UNTUK PRODUKSI UBI KAYU (Manihot utilisima) PADA LAHAN KERING DI KECAMATAN TANJUNGSIANG, KABUPATEN SUBANG
}

\section{ANALYSIS OF POTENTIAL SOIL DEGRADATION TO PRODUCE CASSAVA (Manihot utilisima) ON DRY LAND AT TANJUNGSIANG DISTRICT, SUBANG REGENCY}

\author{
Budy Frasetya Taufik Qurrahman ${ }^{1)}$, Abraham Suriadikusuma ${ }^{2)}$, dan Rachmat Haryanto ${ }^{1)}$ \\ ${ }^{1)}$ Mahasiswa Program Magister Fakultas Pertanian Universitas Padjadjaran \\ ${ }^{2)}$ Fakultas Pertanian Universitas Padjajaran, Jl. Raya Jatinangor Km 21 Sumedang \\ Korespondensi : budyftq1682@gmail.com
}

Diterima 8 Oktober 2014/ Disetujui 8 Desember 2014

\begin{abstract}
ABSTRAK
Penggunaan lahan kering untuk produksi ubi kayu secara intensif tanpa menerapkan teknik budidaya ubi kayu secara lestari dan berkelanjutan di Kecamatan Tanjungsiang berpotensi menyebabkan kerusakan tanah. Penetapan Potensi Kerusakan Tanah dan Status Kerusakan Tanah telah diatur oleh pemerintah pusat melalui Peraturan Pemerintah Nomor 150 Tahun 2000, Peraturan Menteri Negara Lingkungan Hidup Tahun 2006 Tentang Tata Cara Pengukuran Kriteria Baku Kerusakan Tanah untuk Produksi Biomassa. Metode penelitian yang digunakan adalah survei deskriptif dengan tahapan penetapan peta potensi kerusakan tanah hasil overlay peta tematik dan penetapan status kerusakan tanah menggunakan metode matching dan skor frekuensi relatif. Hasil penelitian diperoleh luas lahan kering di Kecamatan Tanjungsiang yang berpotensi rusak sedang 846,07 hektar dan potensi kerusakan tinggi 431,86 hektar setelah dilakukan survei dan analisis laboratorium contoh tanah pada lokasi tersebut diperoleh hasil bahwa Status Kerusakan Tanah pada lokasi dengan potensi kerusakan sedang dan tinggi termasuk kategori Rusak Ringan (R.I) dengan nilai skor frekuensi relatif masing-masing 8. Luas wilayah yang termasuk rusak ringan $1.277,93$ hektar $(19,02 \%)$ parameter yang termasuk Rusak Berat yaitu Kecepatan Infiltrasi dan Potensial Redoks, sedangkan parameter lainnya termasuk kategori Tidak Rusak (N).
\end{abstract}

Kata kunci: Kerusakan Tanah, Penggunaan Lahan, Ubi kayu

\begin{abstract}
Intensively land use of dry land for cassava productions without applying sustainable and sustained cassava farming technique in District Tanjungsiang potentially causes soil degradation. Determination of soil potential degradation and soil degradation status has been set by the central government through Government Regulation No. 150 year 2000, Regulation of the Minister of Environment in year 2006 on the Procedures for Measuring Soil degradation Standard Criteria for Biomass Production. The research method used was a descriptive survey with a stage-setting soil potential degradation by overlay thematic maps and the determination of the status of soil degradation using matching methods and relative frequency
\end{abstract}


score. Results obtained in the dry land area of the District Tanjungsiang potentially medium degradation 846,07 hectares and 431,86 hectares of high potential degradation after survey and laboratory analysis of soil samples at the site that results obtained degradation status of land on the location of the degradation potential to medium and high soil degradation categorized light (R.I) with a score relative frequency of each 8. Total area that included minor damage 1277,93 hectares (19,02\%), parameters included Heavy Damage namely Infiltration Rate and Redox Potential, while the other parameters included on Not Damaged ( $N$ ) category.

Key words: Cassava, Land Use, Soil Degradation

\section{PENDAHULUAN}

Ubi kayu merupakan tanaman pangan yang dianggap oleh sebagian orang sebagai komoditas bernilai ekonomis rendah dan ditanam petani dalam skala kecil. Seiring dengan perkembangan teknologi pengolahan, teknologi pengemasan makanan serta adanya pergeseran pola konsumsi masyarakat kelas ekonomi menengah keatas, ubi kayu kembali diminati masyarakat dalam bentuk olahan salah satunya sebagai makanan ringan.

Berdasarkan data FAO (2013) sejak tahun 2000-an produksi ubi kayu dunia terus meningkat diperkirakan mencapai 100 juta ton. Peningkatan permintaan ubi kayu berdampak positif terhadap meningkatnya harga jual ubi kayu di tingkat petani. Harga komoditas ubi kayu yang terus membaik, mendorong petani untuk memproduksi ubi kayu sebanyakbanyaknya dengan cara memperluas areal tanam, meningkatkan indeks penanaman (IP), menanam varietas unggul yang berumur genjah dan tahan hama penyakit tertentu.

Produksi ubi kayu secara intensif tanpa menerapkan teknik budidaya ubi kayu secara lestari dan berkelanjutan berpotensi menyebabkan kerusakan tanah. Kerusakan tanah menurut Peraturan Pemerintah Nomor 150 Tahun 2000 adalah berubahnya sifat dasar tanah (sifat fisika, sifat kimia dan sifat biologi) melampaui kriteria baku kerusakan tanah.

Berdasarkan data Subang dalam Angka Tahun 2012 dari Badan Pusat Statistik (BPS) Produksi ubi kayu di Kecamatan Tanjungsiang pada tahun 2012 sebesar 2.948,18 ton. Kecamatan Tanjungsiang merupakan kecamatan kedua tertinggi produksi ubikayu di Kabupaten Subang setelah Kecamatan Pabuaran. Berdasarkan pada pertimbangan tersebut $\mathrm{di}$ atas diperlukan penelitian untuk mengetahui status kerusakan tanah untuk produksi ubi kayu di Kecamatan Tanjungsiang Kabupaten Subang.

\section{BAHAN DAN METODE}

Penelitian ini telah dilaksanakan dari bulan April sampai dengan Juni 2014 di Kecamatan Tanjungsiang, Kabupaten Subang. Bahan utama yang digunakan dalam penelitian ini adalah tanah di wilayah Kecamatan Tanjungsiang, Kabupaten Subang, sedangkan bahan penunjang lainnya, yaitu: Peta dasar menggunakan peta Rupa Bumi Indonesia (RBI) skala $1: 25.000$ dikeluarkan oleh Badan Koordinasi Survey dan Pemetaan Nasional (Bakosurtanal), Peta Rencana Tata Ruang Wilayah (RTRW) Kabupaten Subang skala 1 : 100.000 dikeluarkan oleh Pemerintah Kabupaten Subang pada tahun 
2011, Peta Jenis Tanah skala 1 : 100.000 dikeluarkan oleh pemerintah Kabupaten Subang pada tahun 2011, Peta Lereng skala 1 : 100.000 dikeluarkan oleh pemerintah Kabupaten Subang pada tahun 2011, Peta Curah Hujan skala 1 : 100.000 dikeluarkan oleh pemerintah Kabupaten Subang pada tahun 2011, Peta Penggunaan Lahan atau penutupan lahan skala 1 : 100.000 yang dikeluarkan pemerintah Kabupaten Subang pada tahun 2011. Alat yang digunakan terdiri dari dua bagian, yaitu peralatan untuk survei pengolahan (GPS Garmin 60CSx, klinometer, pH meter lapang, EC meter, kamera digital, bor tanah, meteran, pisau, ring sampel, cangkul, alat tulis), peralatan pengolahan data dan penulisan hasil penelitian (Perangkat keras (hardware): Komputer, scanner, printer Perangkat lunak (software): Microsoft Office Versi 2007, Arc GIS Versi 9.3, ENVI versi 4.7)

Metode penelitian yang digunakan dalam penelitian ini adalah metode survei deskriftif komparatif melalui pendekatan analitik dan analisis laboratorium. Tahapan penelitian ini dimulai dengan membuat peta kerja berupa kondisi awal tanah yang diperoleh dengan cara melakukan tumpang susun (overlay) peta-peta tematik, yaitu : peta penggunaan lahan, peta jenis tanah, peta curah hujan peta topografi, peta Rencana Tata Ruang Wilayah (RTRW) Kabupaten Subang dan peta batas adminitrasi kabupaten. Proyeksi peta yang digunakan dalam penelitian ini adalah UTM (Universal Transverse Mercator) masingmasing peta tematik proyeksinya diseragamkan menjadi UTM. Proses tumpang susun peta tematik akan menghasilkan peta kerja berupa area kerja efektif yaitu kawasan budidaya pertanian lahan kering di Kacamatan Tanjungsiang.
Tahapan selanjutnya adalah skoring potensi kerusakan tanah mengacu pada Pedoman Teknis Penyusunan Peta Status Kerusakan Tanah Untuk Produksi Biomassa dari Kementerian Lingkungan Hidup Tahun 2009. Skoring diperoleh dari hasil perkalian nilai rating yaitu nilai potensi masingmasing unsur peta tematik terhadap terjadinya kerusakan tanah dengan nilai bobot masing-masing peta tematik (peta jenis tanah, peta topografi, peta curah hujan, peta penggunaan lahan). Nilai rating ditetapkan dari 1 sampai 5 . Nilai Bobot didasarkan kepada akurasi dari masingmasing informasi peta tematik dalam penilaian potensi kerusakan tanah. Peta penggunaan lahan dan peta tanah diberi nilai bobot dua (2) dan peta kelerengan dan curah hujan diberi bobot tiga (3).

Pada tahap ini potensi kerusakan tanah diduga dengan melakukan pengelompokkan terhadap akumulasi skor pembobotan yaitu hasil kali nilai skor dengan bobot masing-masing peta tematik. Penilaian ini dilakukan pada poligonpoligon hasil overlay. Nilai terendah adalah 10 dan nilai tertinggi 50 , pada prinsipnya semakin tinggi nilai skor pada setiap poligon semakin tinggi pula area tersebut berpotensi mengalami kerusakan tanah. Kriteria pengelompokkan potensi kerusakan tanah disajikan pada Tabel 1. Pada tahap ini sudah diperoleh peta kondisi awal atau peta kerja efektif kerusakan tanah berupa data spasial yang berisi atribut potensi kerusakan tanah di Kecamatan Tanjungsiang, Kabupaten Subang. 
Tabel 1. Kriteria Pembagian Kelas Potensi Kerusakan Tanah Berdasarkan Nilai Skor

\begin{tabular}{ccc}
\hline Simbol & Potensi Kerusakan Tanah & Skor Pembobotan \\
\hline PR.I & Sangat rendah & $<15$ \\
PR.II & Rendah & $15-24$ \\
PR.III & Sedang & $25-34$ \\
PR.IV & Tinggi & $35-44$ \\
PR.V & Sangat tinggi & $45-50$ \\
\hline
\end{tabular}

Sumber: Kementerian Lingkungan Hidup (2009)

Setelah kelas potensi kerusakan tanah lahan kering di Kecamatan Tanjungsiang diperoleh, selanjutnya adalah pengambilan sampel tanah terganggu dan tidak terganggu pada setiap kelas potensi kerusakan tanah. Setiap kelas potensi kerusakan tanah masing-masing diambil 3 (tiga) titik sampel sehingga diperoleh 6 contoh tanah terganggu dan tidak terganggu. Penetapan status kerusakan tanah di lahan kering berdasarkan pada 10 parameter kriteria kerusakan tanah bedasarkan pada Peraturan Pemerintah Nomor 150 Tahun 2000, yaitu: ketebalan solum, kebatuan permukaan, komposisi fraksi, berat isi, porositas total, derajat pelulusan air, $\mathrm{pH}\left(\mathrm{H}_{2} \mathrm{O}\right)$, daya hantar listrik (DHL), Redoks, Jumlah Mikroba. Ambang kritis dari masing-masing parameter kriteria kerusakan tanah terdapat pada Tabel 2.

Tabel 2. Kriteria Baku Kerusakan Tanah di Lahan Kering

\begin{tabular}{cllc}
\hline No. & \multicolumn{1}{c}{ Parameter } & \multicolumn{1}{c}{ Ambang Kritis (PP 150/2000) } & Satuan \\
\hline 1. & Ketebalan Solum & $<20 \mathrm{~cm}$ & $\mathrm{~cm}$ \\
2. & Kebatuan Permukaan & $>40 \%$ & $\%$ \\
3. & Komposisi Fraksi & $<18 \%$ koloid; $>80 \%$ pasir kuarsitik & $\%$ \\
4. & Berat Isi (BI) & $>1,4 \mathrm{~g} \mathrm{~cm}^{-3}$ & $\mathrm{~g} \mathrm{~cm}^{-3}$ \\
5. & Porositas Total & $<30 \% ; 70 \%$ & $\%$ \\
6. & Derajat Pelulusan Air & $<0,7 \mathrm{~cm} \mathrm{jam}^{-1} ;>8 \mathrm{~cm} \mathrm{jam}^{-1}$ & $\mathrm{~cm} \mathrm{jam}^{-1}$ \\
7. & pH $\left(\mathrm{H}_{2} \mathrm{O}\right) 1: 2,5$ & $<4,5 ; 8,5$ & \\
8. & Daya Hantar Listrik/ DHL & $>4,0 \mathrm{mS} \mathrm{cm}^{-1}$ & $\mathrm{mS} \mathrm{cm}^{-1}$ \\
9. & Redoks & $<200 \mathrm{mV}^{-1}$ & $\mathrm{mV}^{-1}$ \\
10. & Jumlah Mikroba & $<10^{2} \mathrm{cfu} \mathrm{g}^{\text {tanah }}$ & $\mathrm{cfu} \mathrm{g}^{-1}$ \\
\hline
\end{tabular}

Sumber: Kementerian Negara Lingkungan Hidup (2006)

Penetapan status kerusakan tanah menggunakan metode matching dan skoring berdasarkan pada frekuensi relatif kerusakan tanah (Tabel 3). Menurut Kementerian Negara Lingkungan Hidup (2009) Frekuensi relatif (\%) kerusakan tanah adalah nilai persentase kerusakan tanah didasarkan perbandingan jumlah contoh tanah yang tergolong rusak yaitu hasil pengukuran setiap parameter kerusakan tanah yang sesuai dengan kriteria baku kerusakan tanah, terhadap jumlah keseluruhan titik pengamatan yang dilakukan dalam poligon tersebut.

Langkah-langkah penetapan status kerusakan tanah sebagai berikut:

1. Hitung frekuensi relatif dari setiap parameter kerusakan tanah

2. Berdasarkan Tabel 3 masing-masing frekuensi relatif tiap parameter kerusakan tanah diberi skor.

3. Nilai skor setiap parameter kerusakan 
tanah dijumlahkan.

4. Penentuan status kerusakan tanah

berdasarkan hasil penjumlahan nilai skor pada langkah 3 berdasarkan pada Tabel 4.

Tabel 3. Skor Kerusakan Tanah Berdasarkan Frekuensi Relatif dari Berbagai Parameter Kerusakan Tanah

\begin{tabular}{ccc}
\hline Frekuensi Relatif Tanah Rusak (\%) & Skor & Status Kerusakan Tanah \\
\hline $0-10$ & 0 & Tidak Rusak \\
$11-25$ & 1 & Rusak Ringan \\
$26-50$ & 2 & Rusak Sedang \\
$51-75$ & 3 & Rusak Berat \\
$76-100$ & 4 & Rusak Sangat Berat \\
\hline
\end{tabular}

Sumber: Kementerian Negara Lingkungan Hidup (2006)

Tabel 4. Status Kerusakan Tanah Berdasarkan Nilai Akumulasi Skor Kerusakan Tanah untuk Lahan Kering

\begin{tabular}{ccc}
\hline Simbol & Status Kerusakan Tanah & Nilai Akumulasi Skor \\
\hline N & Tidak Rusak & 0 \\
R.I & Rusak Ringan & $1-14$ \\
R.II & Rusak Sedang & $15-24$ \\
R.III & Rusak Berat & $25-34$ \\
R.IV & Rusak Sangat Berat & $35-40$ \\
\hline
\end{tabular}

Sumber: Kementerian Negara Lingkungan Hidup (2006)

\section{HASIL DAN PEMBAHASAN}

\section{Karakteristik Lokasi Pengambilan Sampel Tanah}

Hasil tumpang susun peta tematik (Gambar 1) diperoleh hasil bahwa penggunaan lahan kering untuk budidaya ubi kayu di Kecamatan Tanjungsiang memiliki potensi kerusakan tanah sedang (846,07 hektar) dan tinggi (431,86 hektar). Menurut Badan Pusat Statistik (2013) luas tanah di Kecamatan Tanjungsiang pada tahun 2011 adalah 6,716 hektar, sekitar $12,59 \%$ lahan kering berpotensi rusak sedang dan $6,43 \%$ berpotensi rusak tinggi. Lahan kering yang berpotensi rusak sedang sebagian besar berada di Desa Gandasoli sisanya tersebar di Desa Cibuluh dan Desa Rancamanggung, sedangkan lahan kering yang berpotensi rusak Tinggi sebagian besar terletak di Desa Rancamanggung dan Cimeuhmal sisanya tersebar di Desa Cibuluh, Cikawung, Tanjungsiang dan Kawungluwuk.

Pengambilan sampel tanah untuk penetapan status kerusakan tanah dilakukan dengan cara purposive sampling berdasarkan pada peta kerja hasil tumpan susun peta tematik. Pada penelitian ini diambil 3 lokasi sampel untuk setiap potensi kerusakan tanah (potensi kerusakan tanah sedang lokasi sampel Gandasoli 1, 2, 3, dan potensi kerusakan tanah tinggi lokasi sampel Rancamanggung $1,2,3)$ masing-masing terdiri dari dua sampel, yaitu sampel tanah utuh dan sampel tanah terganggu. Titik koordinat dan karakteristik lokasi pengambilan sampel dapat dilihat pada Tabel 5. 


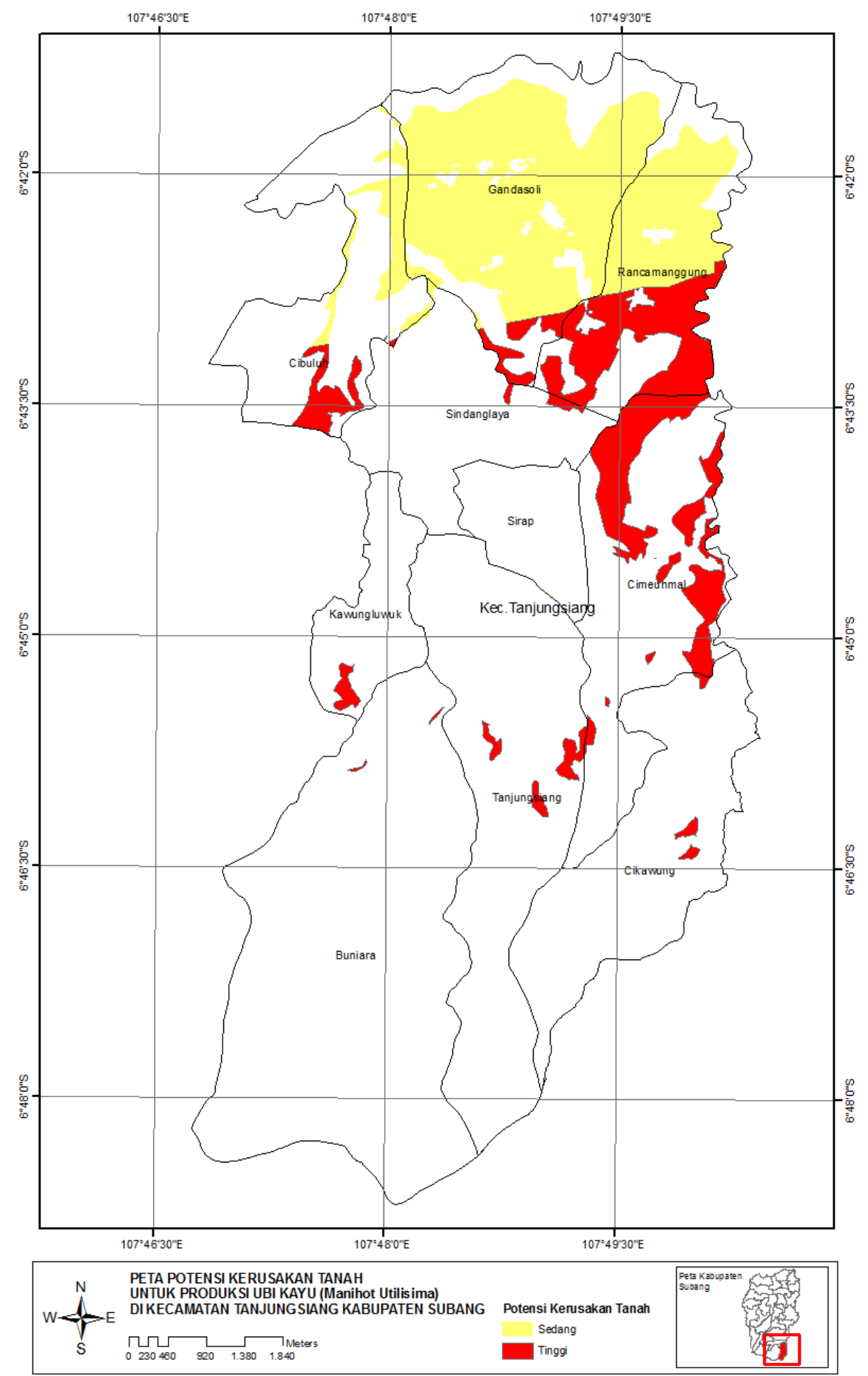

Gambar 1. Peta Potensi Kerusakan Tanah untuk Produksi Ubi Kayu (Manihot Utilismal di Kecamatan Tanjungsiang, Kabupaten Sumedang 
Tabel 5. Titik Koordinat dan Karakteristik Lokasi Pengambilan Sampel Tanah

\begin{tabular}{|c|c|c|c|c|c|c|c|}
\hline \multirow{2}{*}{ No. } & \multirow{2}{*}{ Lokasi Sampel } & \multicolumn{2}{|c|}{ Koordinat } & \multirow{2}{*}{$\begin{array}{c}\text { Lereng } \\
(\%)\end{array}$} & \multirow{2}{*}{$\begin{array}{c}\text { Penggunaan } \\
\text { Lahan }\end{array}$} & \multirow{2}{*}{ Vegetasi } & \multirow{2}{*}{$\begin{array}{c}\text { Bentuk } \\
\text { Erosi }\end{array}$} \\
\hline & & Lintang (LS) & Bujur (BT) & & & & \\
\hline 1. & Gandasoli-1 & 6,70399 & 107,82111 & $8-15$ & Tegalan & Ubi Kayu & Permukaan \\
\hline 2. & Gandasoli-2 & 6,70233 & 107,82261 & $8-15$ & Tegalan & Ubi Kayu & Tidak ada \\
\hline 3. & Gandasoli-3 & 6,69859 & 107,81594 & $8-15$ & Tegalan & Ubi Kayu & Tidak ada \\
\hline 4. & Rancamanggung-1 & 6,72118 & 107,82205 & $8-15$ & Tegalan & $\begin{array}{l}\text { Ubi Kayu, } \\
\text { Kencur }\end{array}$ & Tidak ada \\
\hline 5. & Rancamanggung-2 & 6,71931 & 107,81956 & $8-15$ & Tegalan & Ubi Kayu & Tidak ada \\
\hline 6. & Rancamanggung-3 & 6,72126 & 107,82026 & $8-15$ & Tegalan & $\begin{array}{l}\text { Ubi Kayu, } \\
\text { Kencur }\end{array}$ & Permukaan \\
\hline
\end{tabular}

Hasil analisis laboratorium untuk parameter reaksi tanah $(\mathrm{pH})$, Daya Hantar Listrik (DHL) dan Potensial Redoks dari enam titik sampel disajikan pada Tabel 6. Reaksi tanah pada lokasi kajian 4,66-5,30 berdasarkan pada kriteria penilaian sifat Kimia Tanah termasuk kategori masam (Staf Pusat Penelitian Tanah, 1983 dalam Hardjowigeno, 2010) tingginya curah hujan (3000 - > $4000 \mathrm{~mm}$ per tahun) pada lokasi sampel merupakan salah satu penyebab tanah dilokasi sampel bereaksi masam.

Ambang kritis daya hantar listrik (DHL) adalah lebih besar dari $4 \mathrm{mS} \mathrm{cm}^{-1}$ hasil pengukuran $\mathrm{DHL}$ pada lokasi sampel lebih kecil dari $4 \mathrm{mS} \mathrm{cm}^{-1}$ dan lebih kecil dari 2 $\mathrm{mS} \mathrm{cm}^{-1}$ menurut Tan (1992) pengaruh salinitas kecil dan dapat diabaikan. Hasil pengukuran Potensial Redoks (Tabel 6) termasuk kategori kritis yaitu lebih kecil dari $200 \mathrm{mV}$ untuk tanah lahan kering. Nilai Potensial Redoks $\left(E_{h}\right)$ terendah adalah 94,90 mV dan tertinggi 133,30 mV. Nilai $E_{h}$ pada lokasi sampel menunjukkan tanah dalam kondisi reduktif. Kondisi ini diduga disebabkan adanya air berlebih karena curah hujan tahunan tinggi $(3000 \mathrm{~mm}$ - > $4000 \mathrm{~mm}$ ) selain itu Menurut Tan (1992) bahan organik tanah segar dianggap membantu pembentukan kondisi tanah reduktif, aktivitas mikroorganisme di dalam tanah dapat menyebabkan kandungan oksigen di dalam tanah menurun sehingga mempengaruhi nilai $E_{h}$. Tingginya aktivitas mikroorganisme di dalam tanah juga ditandai banyaknya jumlah populasi mikroba pada lokasi sampel rata-rata jumlah populasi mikroba $16,65 \times 10^{6} \mathrm{cfu}^{-}$ 1 , jumlah tersebut lebih banyak dari ambang kritis lebih kecil (<) $10^{2} \mathrm{cfu} \mathrm{g}^{-1}$.

Tabel 6. Hasil Analisis Laboratorium Reaksi Tanah (pH), Daya Hantar Listrik (DHL), Potensial Redoks dan Jumlah Populasi Mikroba

\begin{tabular}{clcccc}
\hline No. & $\begin{array}{c}\text { Lokasi } \\
\text { Sampel }\end{array}$ & $\begin{array}{c}\mathrm{pH} \\
\mathrm{H}_{2} \mathrm{O}\end{array}$ & $\begin{array}{c}\mathrm{DHL} \\
\left(\mathrm{mS} \mathrm{cm}^{-1}\right)\end{array}$ & $\begin{array}{c}\text { Potensial Redoks } \\
(\mathrm{mV})\end{array}$ & $\begin{array}{c}\text { Mikroba } \\
\left(\mathrm{cfu} \mathrm{g}^{-1}\right) \times 10^{6}\end{array}$ \\
\hline 1 & Gandasoli -1 & 5,01 & 0,19 & 112,60 & 17,34 \\
2 & Gandasoli -2 & 4,66 & 0,15 & 133,30 & 15,63 \\
3 & Gandasoli -3 & 4,91 & 0,15 & 117,70 & 17,57 \\
4 & Rancamanggung-1 & 5,30 & 0,13 & 94,90 & 15,46 \\
5 & Rancamanggung-2 & 4,93 & 0,14 & 116,90 & 17,91 \\
6 & Rancamanggung-3 & 4,85 & 0,13 & 121,20 & 15,97 \\
\hline
\end{tabular}

Hasil analisis laboratorium pada Tabel 7 untuk paramater Komposisi Fraksi, Berat Isi, Prorositas, dan hasil pengukuran lapangan Laju Infiltrasi diperoleh data bahwa kecepatan infiltrasi pada lokasi sampel melebihi ambang kritis, yaitu diatas 
$8 \mathrm{~cm} \mathrm{jam}^{-1}$ sedangkan Komposisi Fraksi, Berat Isi, Porositas Total berada pada kondisi normal menurut kriteria baku kerusakan tanah dari Kementerian Negara Lingkungan Hidup.

Tabel 7. Hasil Analisis Laboratorium Komposisi Fraksi, Berat Isi, Porositas Total dan Hasil Pengukuran Lapangan Laju Infiltrasi

\begin{tabular}{ccccccc}
\hline No. & $\begin{array}{c}\text { Lokasi } \\
\text { Sampel }\end{array}$ & Koloid & $\begin{array}{c}\text { Pasir } \\
\text { Kuarsitik }\end{array}$ & $\begin{array}{c}\text { Kerat Isi } \\
\left(\mathrm{g} \mathrm{cm}^{-3}\right)\end{array}$ & $\begin{array}{c}\text { Porositas } \\
\text { Total }(\%)\end{array}$ & $\begin{array}{c}\text { Infiltrasi } \\
\left(\mathrm{cm} \mathrm{jam}^{-1}\right)\end{array}$ \\
\cline { 3 - 5 } 1. & Gandasoli -1 & 75 & 9 & 1,03 & 49,16 & 36,92 \\
2. & Gandasoli -2 & 74 & 7 & 0,99 & 55,37 & 33,60 \\
3. & Gandasoli -3 & 75 & 7 & 0,91 & 61,36 & 21,60 \\
4. & Rancamanggung-1 & 66 & 13 & 0,92 & 60,15 & 32,00 \\
5. & Rancamanggung-2 & 68 & 11 & 0,90 & 58,91 & 60,00 \\
6. & Rancamanggung-3 & 62 & 15 & 0,86 & 65,06 & 38,4 \\
\hline
\end{tabular}

Menurut Sukisno et al. (2011) tanah yang memiliki porositas total besar akan memiliki laju infiltrasi yang tinggi pula akan tetapi kemampuan tanah dalam meluluskan air tidak hanya dipengaruhi porositas akan tetapi ketebalan solum juga ikut berperan. Besarnya persentase porositas total ditandai tingginya komposisi koloid fraksi liat dengan rata-rata $70 \%$, menurut Sarief (1989) tanah bertekstur halus akan mempunyai persentase ruang pori total lebih tinggi daripada tanah berstekstur kasar.

Hasil pengamatan di lapangan untuk parameter Ketebalan Solum dan Kebatuan Permukaan disajikan pada Tabel 8. Ketabalan solum pada lokasi tersebut lebih dari $150 \mathrm{~cm}$ berarti ketebalan solum pada lokasi pengambilan sampel tidak berada dibawah ambang kritis yaitu dibawah 20 $\mathrm{cm}$, sedangkan kebatuan permukaan juga tidak termasuk rusak karena lebih kecil dari $40 \%$.

Tabel 8. Hasil Pengamatan Lapangan Ketebalan Solum dan Kebatuan Permukaan pada Lokasi Pengambilan Sampel Tanah

\begin{tabular}{|c|c|c|c|c|c|}
\hline \multirow{2}{*}{ No. } & \multirow{2}{*}{$\begin{array}{l}\text { Lokasi } \\
\text { Sampel }\end{array}$} & \multicolumn{2}{|c|}{ Koordinat } & \multirow{2}{*}{$\begin{array}{l}\text { Ketebalan solum } \\
(\mathrm{cm})\end{array}$} & \multirow{2}{*}{$\begin{array}{c}\text { Kebatuan Permukaan } \\
(\%)\end{array}$} \\
\hline & & Lintang (LS) & Lintang (LS) & & \\
\hline 1. & Gandasoli-1 & 6,70399 & 6,70399 & $>150 \mathrm{~cm}$ & 1 \\
\hline 2. & Gandasoli-2 & 6,70233 & 6,70233 & $>150 \mathrm{~cm}$ & 1 \\
\hline 3. & Gandasoli-3 & 6,69859 & 6,69859 & $>150 \mathrm{~cm}$ & 1 \\
\hline 4. & Rancamanggung-1 & 6,72118 & 6,72118 & $>150 \mathrm{~cm}$ & 5 \\
\hline 5. & Rancamanggung-2 & 6,71931 & 6,71931 & $>150 \mathrm{~cm}$ & 12 \\
\hline 6. & Rancamanggung-3 & 6,72126 & 6,72126 & $>150 \mathrm{~cm}$ & 13 \\
\hline
\end{tabular}

\section{Penetapan Status Kerusakan Tanah}

\section{Metode Matching}

Berdasarkan hasil metode matching (Tabel 9 dan 10) pada lokasi sampel dengan potensi kerusakan tanah sedang dan potensi kerusakan tanah tinggi, parameter yang termasuk kategori rusak adalah parameter Derajat Pelulusan Air dan Potensial Redoks. 
Tabel 9. Hasil Metode Matching pada Tanah Potensi Rusak Sedang

\begin{tabular}{|c|c|c|c|c|c|c|c|c|c|}
\hline \multirow{3}{*}{$\begin{array}{l}\text { No. } \\
1 .\end{array}$} & \multirow[t]{2}{*}{ Parameter } & \multirow{2}{*}{$\begin{array}{l}\text { Ambang Kritis } \\
\text { (PP 150/2000) }\end{array}$} & \multirow{2}{*}{ Satuan } & \multicolumn{6}{|c|}{ Lokasi Sampel } \\
\hline & & & & \multicolumn{2}{|c|}{ Gandasoli-1 } & \multicolumn{2}{|c|}{ Gandasoli-2 } & \multicolumn{2}{|c|}{ Gandasoli-3 } \\
\hline & Ketebalan Solum & $<20 \mathrm{~cm}$ & $\mathrm{~cm}$ & $>150$ & $\mathrm{~N}$ & $>150$ & $\mathrm{~N}$ & $>150$ & $\mathrm{~N}$ \\
\hline 2. & $\begin{array}{l}\text { Kebatuan } \\
\text { Permukaan }\end{array}$ & $>40 \%$ & $\%$ & 1 & $\mathrm{~N}$ & 1 & $\mathrm{~N}$ & 1 & $\mathrm{~N}$ \\
\hline 3. & Komposisi Fraksi & $\begin{array}{l}<18 \% \text { koloid; } \\
>80 \% \text { pasir } \\
\text { kuarsitik }\end{array}$ & $\%$ & $\begin{array}{c}75 \\
9\end{array}$ & $\mathrm{~N}$ & $\begin{array}{c}74 \\
7\end{array}$ & $\mathrm{~N}$ & $\begin{array}{c}75 \\
7\end{array}$ & $\mathrm{~N}$ \\
\hline 4. & Berat Isi (BI) & $>1,4 \mathrm{~g} \mathrm{~cm}^{-3}$ & $\mathrm{~g} \mathrm{~cm}^{-3}$ & 1,03 & $\mathrm{~N}$ & 0,99 & $\mathrm{~N}$ & 0,91 & $\mathrm{~N}$ \\
\hline 5. & Porositas Total & $<30 \% ;>70 \%$ & $\%$ & 49,16 & $\mathrm{~N}$ & 55,37 & $\mathrm{~N}$ & 61,36 & $\mathrm{~N}$ \\
\hline 6. & $\begin{array}{l}\text { Derajat Pelulusan } \\
\text { Air }\end{array}$ & $\begin{array}{l}<0,7 \mathrm{~cm} \mathrm{jam}^{-1} \\
>8 \mathrm{~cm} \mathrm{jam}^{-1}\end{array}$ & $\mathrm{~cm} \mathrm{jam}^{-1}$ & 36,92 & $\mathrm{R}$ & 33,60 & $\mathrm{R}$ & 21,60 & $\mathrm{R}$ \\
\hline 7. & $\mathrm{pH}\left(\mathrm{H}_{2} \mathrm{O}\right) 1: 2,5$ & $<4,5 ;>8,5$ & & 5,01 & $\mathrm{~N}$ & 4,66 & $\mathrm{~N}$ & 4,91 & $\mathrm{~N}$ \\
\hline 8. & $\begin{array}{l}\text { Daya Hantar Listrik/ } \\
\text { DHL }\end{array}$ & $>4,0 \mathrm{mS} \mathrm{cm}^{-1}$ & $\mathrm{mS} \mathrm{cm}{ }^{-1}$ & 0,19 & $\mathrm{~N}$ & 0,15 & $\mathrm{~N}$ & 0,15 & $\mathrm{~N}$ \\
\hline 9. & Redoks & $<200 \mathrm{mV}$ & $\mathrm{mV}$ & 112,60 & $\mathrm{R}$ & 133,30 & $\mathrm{R}$ & 117,70 & $\mathrm{R}$ \\
\hline 10. & Jumlah Mikroba & $\begin{array}{l}<10^{2} \text { cfu g }{ }^{-1} \\
\text { tanah }\end{array}$ & cfu g $^{-1}$ & $\begin{array}{r}17,34 \\
\times 10^{6} \\
\end{array}$ & $\mathrm{~N}$ & $\begin{array}{l}15,63 \\
\times 10^{6} \\
\end{array}$ & $\mathrm{~N}$ & $\begin{array}{l}17,57 \\
\times 10^{6} \\
\end{array}$ & N \\
\hline
\end{tabular}

Keterangan : $\mathrm{N}=$ Tidak Rusak; $\mathrm{R}$ = Rusak

Tabel 10. Hasil Metode Matching Pada Tanah Potensi Rusak Tinggi

\begin{tabular}{|c|c|c|c|c|c|c|c|c|c|}
\hline \multirow[t]{2}{*}{ No. } & \multirow[t]{2}{*}{ Parameter } & \multirow{2}{*}{$\begin{array}{l}\text { Ambang Kritis } \\
\text { (PP 150/2000) }\end{array}$} & \multirow{2}{*}{ Satuan } & \multicolumn{6}{|c|}{ Lokasi Sampel } \\
\hline & & & & Gandas & $\mid \mathrm{i}-1$ & Gandas & $i-2$ & Gandas & \\
\hline 1. & Ketebalan Solum & $<20 \mathrm{~cm}$ & $\mathrm{~cm}$ & $>150$ & $\mathrm{~N}$ & $>150$ & $\mathrm{~N}$ & $>150$ & $\mathrm{~N}$ \\
\hline 2. & $\begin{array}{l}\text { Kebatuan } \\
\text { Permukaan }\end{array}$ & $>40 \%$ & $\%$ & 5 & $\mathrm{~N}$ & 12 & $\mathrm{~N}$ & 13 & $\mathrm{~N}$ \\
\hline 3. & Komposisi Fraksi & $\begin{array}{l}<18 \% \text { koloid; } \\
>80 \% \text { pasir } \\
\text { kuarsitik }\end{array}$ & $\%$ & $\begin{array}{l}66 \\
13\end{array}$ & $\mathrm{~N}$ & $\begin{array}{l}68 \\
11\end{array}$ & $\mathrm{~N}$ & $\begin{array}{l}62 \\
15\end{array}$ & $\mathrm{~N}$ \\
\hline 4. & Berat Isi (BI) & $>1,4 \mathrm{~g} \mathrm{~cm}^{-3}$ & $\mathrm{~g} \mathrm{~cm}^{-3}$ & 0,92 & $\mathrm{~N}$ & 0,90 & $\mathrm{~N}$ & 0,86 & $\mathrm{~N}$ \\
\hline 5. & Porositas Total & $<30 \% ;>70 \%$ & $\%$ & 60,15 & $\mathrm{~N}$ & 58,91 & $\mathrm{~N}$ & 65,06 & $\mathrm{~N}$ \\
\hline 6. & $\begin{array}{l}\text { Derajat Pelulusan } \\
\text { Air }\end{array}$ & $\begin{array}{l}<0,7 \mathrm{~cm} \mathrm{jam}^{-1} \\
>8 \mathrm{~cm} \mathrm{jam}^{-1}\end{array}$ & $\mathrm{~cm} \mathrm{jam}^{-1}$ & 32,00 & $\mathrm{R}$ & 60,00 & $\mathrm{R}$ & 38,40 & $\mathrm{R}$ \\
\hline 7. & $\mathrm{pH}\left(\mathrm{H}_{2} \mathrm{O}\right) 1: 2,5$ & $<4,5 ;>8,5$ & & 5,30 & $\mathrm{~N}$ & 4,93 & $\mathrm{~N}$ & 4,85 & $\mathrm{~N}$ \\
\hline 8. & $\begin{array}{l}\text { Daya Hantar Listrik/ } \\
\text { DHL }\end{array}$ & $>4,0 \mathrm{mS} \mathrm{cm}^{-1}$ & $\mathrm{mS} \mathrm{cm}{ }^{-1}$ & 0,13 & $\mathrm{~N}$ & 0,14 & $N$ & 0,13 & $\mathrm{~N}$ \\
\hline 9. & Redoks & $<200 \mathrm{mV}$ & $\mathrm{mV}$ & 94,90 & $\mathrm{R}$ & 116,90 & $\mathrm{R}$ & 121,20 & $\mathrm{R}$ \\
\hline 10. & Jumlah Mikroba & $\begin{array}{l}<10^{2} \text { cfu g } \mathrm{g}^{-1} \\
\text { tanah }\end{array}$ & $\mathrm{cfu} \mathrm{g}^{-1}$ & $\begin{array}{c}15,46 \\
10^{6}\end{array}$ & $\mathrm{~N}$ & $\begin{array}{c}17,91 \\
10^{6}\end{array}$ & $\mathrm{~N}$ & $\begin{array}{c}15,97 \\
10^{6}\end{array}$ & $\mathrm{~N}$ \\
\hline
\end{tabular}

Keterangan : $\mathrm{N}=$ Tidak Rusak; $\mathrm{R}=$ Rusak

\section{Metode Skoring dari Frekuensi Relatif}

Hasil dari metode matching berguna untuk tahapan selanjutnya, yaitu menentukan skor dan penetapan status kerusakan tanah berdasarkan frekuensi relatif. Pemberian skor frekuensi relatif pada setiap parameter kerusakan tanah berdasarkan pada Tabel 3, sedangkan penetapan Status Kerusakan Tanah berdasarkan pada Tabel 4.

Tabulasi penilaian berdasarkan frekuensi relatif pada tahapan ini diperoleh hasil bahwa lahan yang memiliki potensi kerusakan tanah sedang dan lahan yang 
memiliki potensi kerusakan tanah tinggi berdasarkan pada Peta Kerja Efektif ditetapkan memiliki Status Kerusakan
Tanah Rusak Ringan (R.I) dengan nilai akumulasi skor delapan (8).

Tabel 11. Penilaian Kerusakan Tanah berdasarkan Persentase Frekuensi Relatif pada Lahan Kering dengan Potensi Kerusakan Tanah Sedang

\begin{tabular}{llcc}
\hline No. & \multicolumn{1}{c}{ Parameter } & $\begin{array}{c}\text { Frekuensi relatif } \\
\text { kerusakan tanah (\%) }\end{array}$ & $\begin{array}{c}\text { Skor frekuensi } \\
\text { relatif }\end{array}$ \\
\hline 1 & Ketebalan Solum & 0 & 0 \\
2 & Kebatuan Permukaan & 0 & 0 \\
3 & Komposisi Fraksi & 0 & 0 \\
4 & Berat Isi (BI) & 0 & 0 \\
5 & Porositas Total & 0 & 0 \\
6 & Derajat Pelulusan Air & 100 & 4 \\
7 & pH ( $\left.\mathrm{H}_{2} \mathrm{O}\right) 1: 2,5$ & 0 & 0 \\
8 & Daya Hantar Listrik/ DHL & 0 & 0 \\
9 & Redoks & 100 & 4 \\
10 & Jumlah Mikroba & 0 & 0 \\
\hline
\end{tabular}

Keterangan: * Status Kerusakan Tanah Termasuk Rusak Ringan

Tabel 12. Penilaian Kerusakan Tanah berdasarkan Persentase Frekuensi Relatif pada Lahan Kering dengan Potensi Kerusakan Tanah Tinggi

\begin{tabular}{clcc}
\hline No. & \multicolumn{1}{c}{ Parameter } & $\begin{array}{c}\text { Frekuensi Relatif } \\
\text { Kerusakan Tanah (\%) }\end{array}$ & $\begin{array}{c}\text { Skor Frekuensi } \\
\text { Relatif }\end{array}$ \\
\hline 1. & Ketebalan Solum & 0 & 0 \\
2. & Kebatuan Permukaan & 0 & 0 \\
3. & Komposisi Fraksi & 0 & 0 \\
4. & Berat Isi (BI) & 0 & 0 \\
5. & Porositas Total & 0 & 0 \\
6. & Derajat Pelulusan Air & 100 & 4 \\
7. & pH ( $\left.\mathrm{H}_{2} \mathrm{O}\right)$ 1 : 2,5 & 0 & 0 \\
8. & Daya Hantar Listrik/ DHL & 0 & 0 \\
9. & Redoks & 100 & 4 \\
10. & Jumlah Mikroba & 0 & 0 \\
\hline & & & $8^{*}$ \\
\hline
\end{tabular}

Keterangan: * Status Kerusakan Tanah Termasuk Rusak Ringan 
Luas wilayah lahan kering dengan Status Kerusakan Tanah Rusak Ringan (R.I) di Kecamatan Tanjungsiang sebesar 1.277,93 hektar atau $19,02 \%$ dari seluruh luas wilayah Kecamatan Tanjungsiang. Meningkatnya intensitas penggunaan lahan tidak secara otomatis berdampak pada kerusakan tanah, manajemen pengelolaan tanah dan pemilihan teknik budidaya yang digunakan dalam budidaya ubi kayu memiliki peran dalam mengurangi dampak kerusakan tanah.

Status Kerusakan Tanah lahan pada kering di Kecamatan Tanjungsiang tergolong Rusak Ringan (R.I), hal ini bukan berarti di lahan tersebut tidak diperlukan usahausaha perbaikan tanah masih diperlukan tindakan perbaikan supaya status kerusakan tanah menjadi Tidak Rusak (N) dan menjaga agar tingkat kerusakannya tidak lebih parah dan meluas.

\section{SIMPULAN}

1. Status Kerusakan Tanah pada lahan kering di Kecamatan Tanjungsiang, Kabupaten Subang tergolong Rusak Ringan (R.I) seluas 1.277,93 hektar atau sekitar $19,02 \%$ dari seluruh luas wilayah Kecamatan Tanjungsiang.

2. Parameter kerusakan tanah pada lokasi penelitian yang tergolong rusak berat adalah parameter Infiltrasi dan Potensial Redoks, kedua parameter ini harus diperbaiki supaya tidak mempengaruhi terhadap kualitas maupun kuantitas hasil produksi ubi kayu. Langkah untuk mengurangi kecepatan infiltrasi dengan pemberian bahan organik harus dilakukan secara cermat, yaitu dengan memastikan bahan organik yang digunakan telah matang atau terdekomposisi sempurna. Pemberian bahan organik yang belum matang dapat menyebabkan kondisi tanah menjadi tereduksi.

\section{DAFTAR PUSTAKA}

Badan Pusat Statistik (BPS). 2013. Subang dalam Angka 2012. Subang: Kantor Badan Pusat Statistik Kabupaten Subang.

Food and Agriculture Organization (FAO). 2013. Save and Grow Cassava A Guide to Sustainable Production Intensification. Roma: Food and Agriculture Organization (FAO) Of The United Nations.

Kementerian Negara Lingkungan Hidup (Kemen LH) Republik Indonesia. 2009. Peraturan Menteri Negara Lingkungan Hidup Nomor 07 Tahun 2006 Tentang Tata Cara Pengukuran Kriteria Baku Kerusakan Tanah untuk Produksi Biomassa.

Kementerian Negara Lingkungan Hidup (Kemen LH) Republik Indonesia. 2009. Pedoman Teknis Penyusunan Peta Kondisi dan Status Kerusakan Tanah untuk Produksi Biomasa.

Peresiden Republik Indonesia. 2000. Peraturan Pemerintah Republik Indonesia Nomor 150 Tahun 2000 Tentang Pengendalian Kerusakan Tanah untuk Produksi Biomassa.

Sukisno, K.S. Hindarto, Hasanudin, dan A.H. Wicaksono. 2011. Pemetaan Potensi dan Status Kerusakan Tanah untuk Mendukung Produktivitas Biomassa di Kabupaten Lebong. Seminar Nasional Budidaya Pertanian, Pengendalian Alih Fungsi Lahan Pertanian 7 Juli 2011, Bengkulu, Indonesia. 